\title{
Metamorphosis of a British laboratory
}

The British fashion for converting public laboratories into self-governing agencies seems to have helped rescue one of the oldest of them from the torpor into which it was driven in the 1970s.

ONCE upon a time, the National Physical Laboratory (NPL) was Britain's pride and joy among laboratories. Indeed, for a few decades after its creation in 1900 , it may have been Britain's only public laboratory of any size and reputation. It was the laboratory at which Watson-Watt invented radar, but even after the Second World War, NPL cut the figure of an intellectual powerhouse, competition from more glamorous places such as Harwell (for atomic energy) and Malvern (for radar and electronics) notwithstanding. In 1957, for example, it startled the British research establishment with a percipient conference on artificial intelligence, complete with an early demonstration of optical character recognition.

Those days have long since gone. The recent history of NPL is a replica of what has happened to British science since the Second World War. In many ways, the laboratory has been lucky; there have been times in the recent past when it may have been saved from extinction only by its responsibility for the maintenance of national standards of length, mass, time and so on - and by fear of the outcry there would have been if such a distinguished place were shut.

Until the end of the 1950 s or thereabouts, NPL was buzzing with projects and ideas. Apart from the flirtation with artificial intelligence (which grew into a substantial but largely unproductive programme of computer technology), it then maintained both Britain's largest tank for testing ship models (now spun off into a separate organization) and a substantial programme of aerodynamic research, wind tunnels and all.

Even so, sustained by the then common British belief that an ounce of flair is worth a pound of effort, NPL was stretched too thin over many of the fields it purported to cover. Although large even by present standards, with more than 2,000 people at its peak, the laboratory could pretend at excellence only in some of the areas of its activity.

Then began the period of recurrent reorganization that has played havoc with a host of British organizations. When the old Department of Scientific and Industrial Research was abolished in 1964, NPL was shunted off to the Board of Trade on the strength of its metrology. Now it is a dependant of the Department of Trade and Industry. Never quite knowing where it belonged, who can be surprised that it may not have known clearly what it was for?

With a little luck, this may now have changed. For just over a year, since July 1990, NPL has been a government agency, which means that it stands on its own feet financially, driven by financial targets set each year by the Department of Trade and Industry, and balancing income (90 per cent of it from the sponsoring department) against expenditure. Small though the outward differences have been so far, this last transformation is probably irreversible. What else could there be except outright privatization (with which the department has been dickering on behalf of another of its laboratories, the National Engineering Laboratory, for the past two years)?

Probably the most noticeable consequence of agency status has been that the 25-hectare site at Teddington, part of southwest London on the left bank of the Thames, looks like a building site. A little to its surprise, one gathers, NPL has persuaded the department to spend $£ 60$ million on a new laboratory block. They are already at work threading heating ducts around the two listed buildings that will have to be preserved when the new block goes up.

The most obvious intangible change is the management of NPL. The director, Dr Peter Clapham, his deputy (and controller, scientific services), $\mathrm{Mr}$ Andrew Wallard, and the heads of the six divisions form the equivalent of a company board which determines policy and allocates resources accordingly. The influence of the sponsoring department is exercised through a steering board, comprising external people and ministry officials.

What are the benefits? Flexibility is the most obvious. Although the people at the laboratory remain civil servants, NPL can now take on contract research without advance reference to its sponsor, hiring the people to do the work outside the usual constraints on manpower. It can also reward exceptional people with promotions that come a little earlier than might otherwise be the case.

The new ethos is that contracts won independently of government sponsors are valued more highly than the contribution they make to turnover. In the last complete financial year, NPL earned $£ 3.4$ million that way - some 7 per cent of its total budget. The obvious advantage is the sense of independence such income engenders. But one member of the staff wryly noted that this is also a way in which the sponsoring department might eventually reduce its obligations.

A few members of the staff seem more enlivened than threatened by the new opportunities. The micrometrology laboratory, for example, is busily fabricating thickness standards in the micron range for use in the chip industry and has designed a laser interferometer, half the size of a match-box, deliberately so that it can be manufactured at a reasonable cost, in the hope that their partner company will sell a few hundreds rather than a few.

Much in the same spirit, the group using lidar measurements for the measurement of atmospheric pollutants has built itself a mobile laboratory, complete with a twin-dye laser system tunable from the infrared to the ultraviolet, which can be driven to the sites of factories suspected as the sources of, say, hydrocarbon pollution. The group's services are much in demand as environmental regulations bite.

The same group is saddled with the task of pinning down Britain's emission of greenhouse gases, to which end it has (among other things) mounted methane detectors around pens of cattle feeding naturally to measure this source of methane directly.

The standards work also survives, apparently in good shape. One group has built on a single chip an array of Josephson junctions in series that will serve as a standard 1 Volt when popped into liquid helium. The goal of relating all the electrical standards to fundamental constants (electronic charge and mass and Planck's constant) is around the corner, and there is even a scheme for linking them with mass as well.

Yet NPL is no longer distinguishable from a British academic laboratory only by its equipment (traditionally better). Peter Clapham says that he is cheered that the past five years' harvest of recruits have readily taken to the idea that their research is no more valuable than they can persuade their sponsors that it is.

But these are early days. The long-term test will be that of whether the sponsors remain loyal to the standards programme, and whether enthusiasm for winning contracts distracts from thoughtfulness. And meanwhile, the professional unions are worrying that success at NPL may bring in an army of people on short-term contracts, without a traditional career structure.

John Maddox 